The Canadian Mineralogist

Vol. 39, pp. 137-144 (2001)

\title{
THE CRYSTAL STRUCTURE OF OLSHANSKYITE
}

\author{
ATHOS CALLEGARI ${ }^{\S}$, FIORENZO MAZZI AND CARLA TADINI \\ CNR Centro di Studio per la Cristallochimica e la Cristallografia, Dipartimento di Scienze della Terra, \\ Università di Pavia, Via Ferrata, 1, I-27100 Pavia, Italy
}

\begin{abstract}
X-ray intensity data for olshanskyite, $\mathrm{Ca}_{2}\left[\mathrm{~B}_{3} \mathrm{O}_{3}(\mathrm{OH})_{6}\right] \mathrm{OH} \cdot 3 \mathrm{H}_{2} \mathrm{O}$, were collected from a crystal from the Fuka mine, Okayama Prefecture, Japan, using a PW1100 Philips single-crystal diffractometer. Olshanskyite is triclinic, $a$ 7.953(4), $b$ 9.873(9), $c$ 7.362 (6) $\AA$, $\alpha 111.00(7), \beta 94.65(7), \gamma 107.53(7)^{\circ}$, space group $P \overline{1}, Z=2$. The crystal structure was solved and refined to $R=0.017$ for 3833 observed reflections and to $R=0.022$ for all unique reflections (4419). The anionic group in the structure is a threemembered ring of boron-oxygen tetrahedra $\left[\mathrm{B}_{3} \mathrm{O}_{3}(\mathrm{OH})_{6}\right]^{3-}$. Two independent calcium atoms occur in a distorted square-antiprism coordination with five oxygen atoms from the borate group and three hydroxyl or $\mathrm{H}_{2} \mathrm{O}$ groups external to the borate cluster. The apparent discrepancies between the unit-cell parameters and the formula unit of olshanskyite resulting from the present research and those previously determined are attributed to two alternative interpretations of the same chemical and X-ray powder data. Analogies and differences between the crystal structure of olshanskyite and that of the analogous borate nifontovite $\mathrm{Ca}_{3}\left[\mathrm{~B}_{3} \mathrm{O}_{3}(\mathrm{OH})_{6}\right]_{2} \cdot 2 \mathrm{H}_{2} \mathrm{O}$ also are discussed. Olshanskyite must be classified as a neso-triborate, and its structure is based on finite borate clusters $(\mathrm{FBB}=3 \square)$.
\end{abstract}

Keywords: olshanskyite, crystal structure, refinement, borate cluster.

\section{SOMMAIRE}

Nous avons prélevé des données de diffraction $\mathrm{X}$ d'un cristal d'olshanskyite, $\mathrm{Ca}_{2}\left[\mathrm{~B}_{3} \mathrm{O}_{3}(\mathrm{OH})_{6}\right] \mathrm{OH} \cdot 3 \mathrm{H}_{2} \mathrm{O}$, provenant de la mine Fuka, préfecture d'Okayama, au Japon, au moyen d'un diffractomètre Philips PW1100. L'olshanskyite est triclinique, $a$ 7.953(4), $b$ 9.873(9), c 7.362 (6) $\mathrm{A}, \alpha$ 111.00(7), $\beta$ 94.65(7), $\gamma 107.53(7)^{\circ}$, groupe spatial $P \overline{1}, Z=2$. La structure cristalline a été résolue et affinée jusqu'à un résidu $R$ de 0.017 pour 3833 réflexions observées ( $R=0.022$ pour toutes les 4419 réflexions uniques). Le module anionique de la structure est un anneau de tétraèdres boratés à trois membres, de composition $\left[\mathrm{B}_{3} \mathrm{O}_{3}(\mathrm{OH})_{6}\right]^{3-}$. Deux atomes indépendants de calcium forment un agencement en antiprisme carré difforme en coordinence avec cinq atomes d'oxygène faisant partie de groupes de borate et trois groupes d'hydroxyle ou de $\mathrm{H}_{2} \mathrm{O}$ externes à l'agencement de borates. Les écarts apparents entre les paramètres réticulaires et l'unité formulaire de l'olshanskyite documentés dans ce travail et ceux qui sont déjà dans la littérature sont attribuables à deux interprétations alternative des mêmes données chimiques et diffractométriques. Nous discutons des ressemblances et des différences structurales entre l'olshanskyite et la nifontovite, $\mathrm{Ca}_{3}\left[\mathrm{~B}_{3} \mathrm{O}_{3}(\mathrm{OH})_{6}\right]_{2} \bullet 2 \mathrm{H}_{2} \mathrm{O}$. L'olshanskyite serait un néso-triborate dont la structure est fondée sur un agencement fini de tétraèdres de borate (FBB = $3 \square$ ).

(Traduit par la Rédaction)

Mots-clés: olshanskyite, structure cristalline, affinement, groupe de tétraèdres de borate.

\section{INTRODUCTION}

Olshanskyite was identified as a new mineral by Bogomolov et al. (1969). At the type locality, it occurs as fibrous aggregates of twinned crystals penetrating fresh sakhaite in the magnesian skarns of eastern Siberia. Kusachi \& Henmi (1994) described superior specimens of olshanskyite, together with nifontovite $\mathrm{Ca}_{3}\left[\mathrm{~B}_{3} \mathrm{O}_{3}(\mathrm{OH})_{6}\right]_{2} \cdot 2 \mathrm{H}_{2} \mathrm{O}$, in the gehlenite-spurrite skarns at Fuka, Okayama Prefecture, Japan, and re- ported physical and chemical properties of both minerals. They provided confirmation of the ideal formula unit $\mathrm{Ca}_{3} \mathrm{~B}_{4}(\mathrm{OH})_{18}$ given by Bogomolov et al. (1969) and established the triclinic unit-cell: $a$ 9.991, $b$ 14.740, $c$ $7.975 \AA, \alpha 94.53^{\circ}, \beta 69.08^{\circ}, \gamma 112.44^{\circ}, Z=3$. Strunz (1997) classified olshanskyite among nesoborates containing $\mathrm{H}_{2} \mathrm{O}$ molecules or additional $\mathrm{OH}$ anions.

We have determined the structure of olshanskyite using a specimen from the Fuka District, Japan and compare it to that of nifontovite herein.

$\S \quad$ E-mail address: callegari@crystal.unipv.it 


\section{EXPERIMENTAL}

An untwinned crystal $(0.34 \times 0.17 \times 0.5 \mathrm{~mm})$ was selected for crystallographic measurements with a fourcircle Philips PW 1100 automated single-crystal diffractometer equipped with graphite-monochromatized MoK $\alpha$ radiation $(\lambda=0.7107 \AA)$. The cell parameters were determined by the least-squares refinement of the $\theta$ values obtained from 60 rows of the reciprocal lattice by measuring the center of gravity of each reflection in the range between 2 and $35^{\circ}(\theta)$. Crystal quality was assessed by the profile and width of Bragg diffraction peaks. Intensity data were collected for the symmetry-equivalent pairs $\overline{h k l}-h k l$ in the range of $2<$ $\theta<35^{\circ}$. Intensities were corrected for absorption by the method of North et al. (1968), Lorentz and polarization effects, averaged and reduced to structure factors.

\section{Determination AND ReFinEMENT of the Crystal Structure}

Details of the X-ray data collection are given in Table 1. A Patterson synthesis provided the sites of two independent calcium atoms (Ca1 and $\mathrm{Ca} 2$ ), whose coordinates were used to calculate the preliminary phases of the structure factors. All sites of the remaining nonhydrogen atoms (i.e., B1, B2, B3 and thirteen oxygen atoms, $\mathrm{O} 1$ to $\mathrm{O} 13$ ) were obtained from successive difference-Fourier syntheses. The refinement was carried out with a largely modified version of the least-squares program ORFLS (Busing et al. 1962) and unit weights for the structure amplitudes. The following scattering factors for neutral or ionized atoms were used: $\mathrm{Ca}^{2+}, \mathrm{B}$, $\mathrm{H}$ and $1 / 2 \mathrm{O}+1 / 2 \mathrm{O}^{2-}$ for the oxygen sites (Ungaretti 1980).

TABLE 1. SUMMARY OF DATA ON X-RAY REFINEMENT OF OLSHANSKYITE

Formula unit: $\mathrm{Ca}_{2}\left[\mathrm{~B}_{3} \mathrm{O}_{3}(\mathrm{OH})_{6}\right](\mathrm{OH}) \cdot 3\left(\mathrm{H}_{2} \mathrm{O}\right)$

X-ray single-crystal diffractometer: Philips PW 1100

Radiation: MoK $\alpha$ monochromatized on graphite

Scan: mode $\omega$, width $1.20^{\circ}$, speed $0.04^{\circ} \%$

Crystal dimensions: $0.34 \times 0.17 \times 0.50 \mu \mathrm{m}$

$\theta$ range: $2-35^{\circ}$

Unit-cell dimensions:

a $7.953(4) \AA$

$\begin{array}{ll}a & 7.953(4) \\ b & 9.873(9)\end{array}$

c $7.362(6)$

Z 2

Space group: $P \overline{1}$

Measured reflections: $8838( \pm h, \pm k, \pm l)$

Unique reflections: 4419

$R_{\text {sym }}\left({ }^{*}\right): 0.021$

"Observed" reflections: $[\mathrm{I} / \sigma(\mathrm{I}) \geq 3]: 3833$

Refinement $R$ factors:

"observed" reflections: 0.017

total unique reflections: 0.022

$\left(^{*}\right) R_{\mathrm{sym}}=\Sigma F^{2}(h k l)-F^{2}(h k T) / \Sigma\left[F^{2}(h k l)+F^{2}(h k l)\right]$

The intensities were corrected for the absorption due to the shape of the sample according to North et al. (1968).
The preliminary refinement with isotropic displacement factors converged to an $R$ of 0.045 for the "observed" $[\mathrm{I} / \sigma(\mathrm{I}) \geq 3]$ reflections; the successive refinement with anisotropic displacement parameters gave an $R$ of 0.026 . At this stage, a difference-Fourier synthesis provided the sites of thirteen hydrogen atoms, which were introduced in the final refinement. The $R$ factor converged to 0.017 for the "observed" reflections and 0.022 for all reflections (Table 1). The formula unit of olshanskyite obtained from the refinement of the crystal structure is $\mathrm{Ca}_{2}\left[\mathrm{~B}_{3} \mathrm{O}_{3}(\mathrm{OH})_{6}\right](\mathrm{OH}) \cdot 3 \mathrm{H}_{2} \mathrm{O}$.

Table 2 gives the final atomic coordinates and the $\mathrm{B}$ equivalent displacement-parameters; the cation-oxygen distances, together with the angles in boron tetrahedra, are reported in Table 3. A bond-valence arrangement is given in Table 4. The anisotropic displacement parameters and the observed and calculated structure-factors may be obtained from The Depository of Unpublished Data, CISTI, National Research Council, Ottawa, Ontario K1A 0S2, Canada.

TABLE 2. ATOMIC COORDINATES AND $B_{\mathrm{EQ}}$ OF OLSHANSKYITE

\begin{tabular}{|c|c|c|c|c|}
\hline Atom & $x$ & $y$ & $z$ & $\mathrm{~B}_{\mathrm{eq}}$ \\
\hline $\mathrm{Ca} 1$ & $0.08117(3)$ & $0.03398(2)$ & $0.25741(2)$ & $0.75(1)$ \\
\hline $\mathrm{Ca} 2$ & $0.11601(2)$ & $0.67181(2)$ & $0.41741(3)$ & $0.82(1)$ \\
\hline B 1 & $0.2840(1)$ & $0.0291(1)$ & $0.6344(1)$ & $0.66(2)$ \\
\hline B 2 & $0.2358(1)$ & $0.2864(1)$ & $0.6911(1)$ & $0.68(2)$ \\
\hline B 3 & $0.5283(1)$ & $0.2874(1)$ & $0.8530(1)$ & $0.73(2)$ \\
\hline $\mathrm{O}_{1}$ & $0.2590(1)$ & $-0.0683(1)$ & $0.4197(1)$ & $0.83(2)$ \\
\hline $\mathrm{O} 2$ & $0.2003(1)$ & $-0.0901(1)$ & $0.7134(1)$ & $0.87(2)$ \\
\hline O 3 & $0.1684(1)$ & $0.1209(1)$ & $0.6453(1)$ & $0.78(1)^{*}$ \\
\hline O 4 & $0.1790(1)$ & $0.3022(1)$ & $0.5027(1)$ & $0.95(2)$ \\
\hline 05 & $0.1296(1)$ & $0.3593(1)$ & $0.8291(1)$ & $0.87(2)$ \\
\hline 06 & $0.4297(1)$ & $0.3589(1)$ & $0.7594(1)$ & $0.79(1)^{*}$ \\
\hline O 7 & $0.7226(1)$ & $0.3539(1)$ & $0.8568(1)$ & $1.03(2)$ \\
\hline 08 & $0.4976(1)$ & $0.3171(1)$ & $1.0597(1)$ & $1.22(2)$ \\
\hline 09 & $0.4693(1)$ & $0.1190(1)$ & $0.7378(1)$ & $0.80(1)^{*}$ \\
\hline $\mathrm{O} 10$ & $0.0691(1)$ & $0.1791(1)$ & $0.0541(1)$ & $1.13(2)$ \\
\hline 011 & $0.3587(1)$ & $0.0524(1)$ & $0.1249(1)$ & $1.65(2)^{* *}$ \\
\hline 012 & $-0.0500(1)$ & 0.3918 (1) & $0.2696(1)$ & $1.28(2)^{* *}$ \\
\hline 013 & $0.3705(1)$ & $0.6072(1)$ & $0.5114(1)$ & $1.51(2)^{* *}$ \\
\hline H 1 & $0.355(3)$ & $-0.077(2)$ & $0.376(3)$ & $3.4(4)$ \\
\hline H 2 & $0.248(2)$ & $-0.063(2)$ & $-0.167(3)$ & $3.1(4)$ \\
\hline $\mathrm{H} 4$ & $0.246(2)$ & $0.382(2)$ & $0.491(3)$ & $3.1(4)$ \\
\hline H 5 & $0.100(2)$ & $0.308(2)$ & $-0.094(3)$ & $2.9(4)$ \\
\hline H 7 & $0.767(2)$ & $0.446(2)$ & $-0.049(3)$ & $2.6(4)$ \\
\hline H 8 & $0.502(2)$ & $0.410(2)$ & $1.115(3)$ & $2.9(4)$ \\
\hline $\mathrm{H} 10$ & $0.182(3)$ & $0.219(2)$ & $0.066(3)$ & $3.4(4)$ \\
\hline H11a & $0.424(3)$ & $0.128(2)$ & $0.103(3)$ & $4.1(5)$ \\
\hline $\mathrm{H} 11 b$ & $0.431(3)$ & $0.010(3)$ & $0.166(3)$ & $4.7(5)$ \\
\hline $\mathrm{H} 12 a$ & $-0.001(3)$ & $0.320(2)$ & $0.199(3)$ & 4.0 (4) \\
\hline $\mathrm{H} 12 b$ & $-0.140(3)$ & $0.379(2)$ & $0.180(3)$ & 3.9 (4) \\
\hline $\mathrm{H} 13 a$ & $0.427(3)$ & $0.648(2)$ & $0.643(3)$ & $3.6(4)$ \\
\hline $\mathrm{H} 13 b$ & $0.452(3)$ & $0.624(2)$ & $0.431(3)$ & $3.3(4)$ \\
\hline
\end{tabular}

All the oxygen atoms belong to hydroxyl groups, except: * oxygen atoms shared between boron tetrahedra, and ${ }^{* *}$ oxygen atoms belonging to $\mathrm{H}_{2} \mathrm{O}$ molecules. The number in the label of each hydrogen atom is equal to the number in the label of the oxygen atom to which it is bonded. Letters $a$ and $b$ identify the two hydrogen atoms of a $\mathrm{H}_{2} \mathrm{O}$ molecule. 
TABLE 3. BOND LENGTHS ( $\AA$ ) AND SELECTED BOND-ANGLES $\left(^{\circ}\right)$ IN OLSHANSKYITE

\begin{tabular}{|c|c|c|c|c|c|c|c|c|}
\hline \multicolumn{3}{|c|}{$\mathrm{Ca} 1-\mathrm{O} 10$} & \multicolumn{2}{|c|}{$2.387(2)$} & $\mathrm{Ca} 2-\mathrm{O} 13$ & \multicolumn{3}{|r|}{$2.419(2)$} \\
\hline \multicolumn{3}{|c|}{-01} & \multicolumn{2}{|c|}{$2.429(1)$} & $-\mathrm{O} 2$ & \multicolumn{3}{|r|}{$2.422(2)$} \\
\hline \multicolumn{3}{|c|}{-010} & \multicolumn{2}{|c|}{$2.430(1)$} & -05 & \multicolumn{3}{|r|}{$2.422(2)$} \\
\hline \multicolumn{3}{|c|}{$-\mathrm{O} 3$} & \multicolumn{2}{|c|}{$2.445(2)$} & -012 & \multicolumn{3}{|r|}{$2.446(2)$} \\
\hline \multicolumn{3}{|c|}{$-\mathrm{O} 4$} & \multicolumn{2}{|c|}{$2.446(2)$} & -07 & \multicolumn{3}{|r|}{$2.457(1)$} \\
\hline \multicolumn{3}{|c|}{-011} & \multicolumn{2}{|c|}{$2.468(2)$} & -01 & \multicolumn{3}{|r|}{$2.467(2)$} \\
\hline \multicolumn{3}{|c|}{$-\mathrm{O} 2$} & \multicolumn{2}{|c|}{$2.470(2)$} & -04 & \multicolumn{3}{|r|}{$2.528(2)$} \\
\hline \multicolumn{3}{|c|}{$-\mathrm{O} 3$} & \multicolumn{2}{|c|}{$2.634(2)$} & -012 & \multicolumn{3}{|r|}{$2.648(2)$} \\
\hline \multicolumn{3}{|c|}{ mean } & \multicolumn{2}{|c|}{2.464} & mean & & & 2.476 \\
\hline B1 & -09 & $1.444(2)$ & B2 & -06 & $1.447(2)$ & B3 & -09 & $1.470(2)$ \\
\hline & $-\mathrm{O} 3$ & $1.461(1)$ & & -03 & $1.456(2)$ & & -06 & $1.477(1)$ \\
\hline & -01 & $1.485(2)$ & & -05 & $1.498(1)$ & & -07 & $1.479(2)$ \\
\hline & $-\mathrm{O} 2$ & $1.499(1)$ & & -04 & $1.499(2)$ & & -08 & $1.499(2)$ \\
\hline mear & & 1.472 & mear & & 1.475 & mean & & 1.481 \\
\hline O9 & $-\mathrm{B} 1-$ & O3 114.4 & O6 & $-\mathrm{B} 2$ & O3 113.7 & 09 & $-\mathrm{B} 3$ & O6 111.3 \\
\hline & & $\begin{array}{ll}01 & 114.9 \\
\mathrm{O} 2 & 111.0\end{array}$ & & & $\begin{array}{ll}05 & 114.9 \\
\text { O4 } & 109.9\end{array}$ & & & $\begin{array}{ll} & 101.4 \\
\text { O8 } & 108.7\end{array}$ \\
\hline $\mathrm{O} 3$ & $-\mathrm{B} 1-$ & O1 106.2 & $\mathrm{O} 3$ & $-\mathrm{B} 2$ & O5 107.7 & O6 & $-\mathrm{B} 3-$ & O7 108.6 \\
\hline 01 & $-\mathrm{B} 1-$ & $\begin{array}{ll}\mathrm{O} 2 & 107.5 \\
\mathrm{O} 2 & 102.0\end{array}$ & O5 & $-\mathrm{B} 2$ & $\begin{array}{ll}\text { O4 } & 106.2 \\
\text { O4 } & 103.8\end{array}$ & O7 & $-\mathrm{B} 3-$ & $\begin{array}{ll}\text { O8 } & 110.1 \\
\text { O8 } & 110.7\end{array}$ \\
\hline $\mathrm{B} 1$ & $-\mathrm{O} 3-$ & B2 123.9 & B2 & -06 & B3 119.2 & B3 & -09 & B1 121.1 \\
\hline
\end{tabular}

The standard deviation in the angles is $0.1^{\circ}$.

\section{DESCRIPTION AND DisCUSSION of the CRystal Structure}

Projections of the crystal structure of olshanskyite along [001] and [100] are shown in Figure 1 and 2, respectively. Both projections reproduce the cluster of borate polyhedra formed by a three-membered ring of boron-oxygen tetrahedra: $\left[\mathrm{B}_{3} \mathrm{O}_{3}(\mathrm{OH})_{6}\right]^{3-}$; only $\mathrm{Ca}-\mathrm{O}$ bonds are shown in Figure 1, and only $\mathrm{O}-\mathrm{H}$... O hydrogen bonds are shown in Figure 2. Both calcium atoms are surrounded by eight atoms of oxygen in a distorted square antiprism coordination. The different components of the crystal structure are roughly arranged on three adjacent planes parallel to $(0 \overline{1} 1)$ : borate tetrahedra are centered on the first plane (Fig. 2); the next contains $\mathrm{Ca}$ atoms; the $\mathrm{H}_{2} \mathrm{O}$ molecules $(\mathrm{O} 11, \mathrm{O} 12, \mathrm{O} 13)$ and the only hydroxyl group (O10) not bonded to boron are arranged on the third plane. This system of atoms, disposed on three planes, is repeated perpendicular to $(0 \overline{1} 1)$ and is alternately inverted according to the symmetry of space group $P \overline{1}$.

\section{The cluster of boron-oxygen tetrahedra}

Figure 3 shows in detail the configuration of the three-membered borate ring, together with the Ca cations connected with them. Formally, the actual ring of tetrahedra can be obtained by independent rotations of each tetrahedron in an ideal ring, in which the boron atoms (B1, B2, B3) and the shared corners of the tetrahedra $(\mathrm{O} 3, \mathrm{O} 6, \mathrm{O} 9)$ are in the same plane. Each tetrahedron is rotated around the edge that lies in the plane (i.e., O9/O3, O3/O6 and O6/O9, respectively). Whereas the
TABLE 4 BOND-VALENCE ARRANGEMENT IN OLSHANSKYITE*

\begin{tabular}{|c|c|c|c|c|c|c|c|c|}
\hline & $\mathrm{Cal}$ & $\mathrm{Ca} 2$ & B1 & B2 & B3 & $\Sigma \mathrm{H}_{\mathrm{don}}$ & $\Sigma \mathrm{H}_{\mathrm{acc}}$ & total \\
\hline 01 & 0.29 & 0.26 & 0.73 & & & 0.76 & & 2.04 \\
\hline $\mathrm{O} 2$ & 0.26 & 0.29 & 0.71 & & & 0.85 & & 2.11 \\
\hline O3 & 0.44 & & 0.78 & 0.80 & & & & 2.02 \\
\hline O4 & 0.27 & 0.22 & & 0.71 & & 0.87 & & 2.07 \\
\hline O5 & & 0.29 & & 0.71 & & 0.82 & 0.19 & 2.01 \\
\hline 06 & & & & 0.81 & 0.75 & & 0.38 & 1.94 \\
\hline O7 & & 0.27 & & & 0.75 & 0.81 & 0.08 & 1.91 \\
\hline 08 & & & & & 0.71 & 0.85 & 0.37 & 1.93 \\
\hline O9 & & & 0.82 & & 0.77 & & 0.40 & 1.99 \\
\hline 010 & 0.61 & & & & & 0.93 & 0.45 & 1.99 \\
\hline 011 & 0.26 & & & & & 1.67 & 0.15 & 2.08 \\
\hline $\mathrm{O} 12$ & & 0.43 & & & & 1.65 & & 2.08 \\
\hline $\mathrm{O} 13$ & & 0.30 & & & & 1.64 & 0.13 & 2.07 \\
\hline total & 2.13 & 2.06 & 3.04 & 3.03 & 2.98 & 10.85 & 2.15 & 26.24 \\
\hline
\end{tabular}

* Calculated after Brown \& Altermatt (1985) with the parameters given by Brese \& O'Keeffe (1991).

$\Sigma \mathrm{H}_{\text {don }}$ and $\Sigma \mathrm{H}_{\text {acc }}$ are the sums of the bond valences corresponding to all $\mathrm{O}$ (donor) $-\mathrm{H}$ or, respectively, $\mathrm{H}$...O(acceptor) bonds.

B2 tetrahedron practically retains its ideal position, the remaining tetrahedra are rotated by nearly $38^{\circ}$ (B3) and $-16^{\circ}(\mathrm{B} 1)$ in opposite directions with respect to the $(\mathrm{O} 3$, O6, O9) plane. The three tetrahedra are bonded to the $\mathrm{Ca}$ atoms differently: the $\mathrm{B} 1$ tetrahedron shares edges with three differing $\mathrm{Ca}$ polyhedra (two $\mathrm{Ca} 1$ and one $\mathrm{Ca} 2$ ), the $\mathrm{B} 2$ tetrahedron shares edges with two Ca polyhedra $(\mathrm{Ca} 1$ and $\mathrm{Ca} 2)$, and the $\mathrm{B} 3$ tetrahedron, which shows the largest deviation from the ideal position in the ring, has only one corner in common with a Ca polyhedron $(\mathrm{Ca} 2)$. The tetrahedra are almost regular; their average B-O lengths are $1.472 \AA$ (B1), $1.475 \AA$ (B2), $1.481 \AA$ (B3). There is some correlation between the geometrical regularity of a tetrahedron and the number of connected Ca polyhedra. The B3 tetrahedron, which shares a corner with only one polyhedron, is the most regular, whereas the B1 tetrahedron, which is connected by edges to three polyhedra, is more distorted (Table 3 ).

\section{The calcium polyhedra}

Both calcium polyhedra are very distorted square antiprisms. Ca1 is coordinated to five oxygen atoms from the borate cluster, two hydroxyl groups (O10) and one $\left(\mathrm{H}_{2} \mathrm{O}\right)$ group $(\mathrm{O} 11)$; $\mathrm{Ca} 2$ is coordinated to five oxygen atoms from the borate cluster and three $\left(\mathrm{H}_{2} \mathrm{O}\right)$ groups $(2 \times \mathrm{O} 12+\mathrm{O} 13)$ (Fig. 1). Apart from the previously described connections by edge- or vertex-sharing with the boron-oxygen tetrahedra, the calcium polyhedra are also interconnected and form a network that extends parallel to (100) (Fig. 4). Chains of Ca1 polyhedra occur along [001] by sharing alternately the edges formed by the centrosymmetrical pairs of oxygen atoms O3-O3 and O10-O10. In addition, couples of $\mathrm{Ca} 2$ poly- 


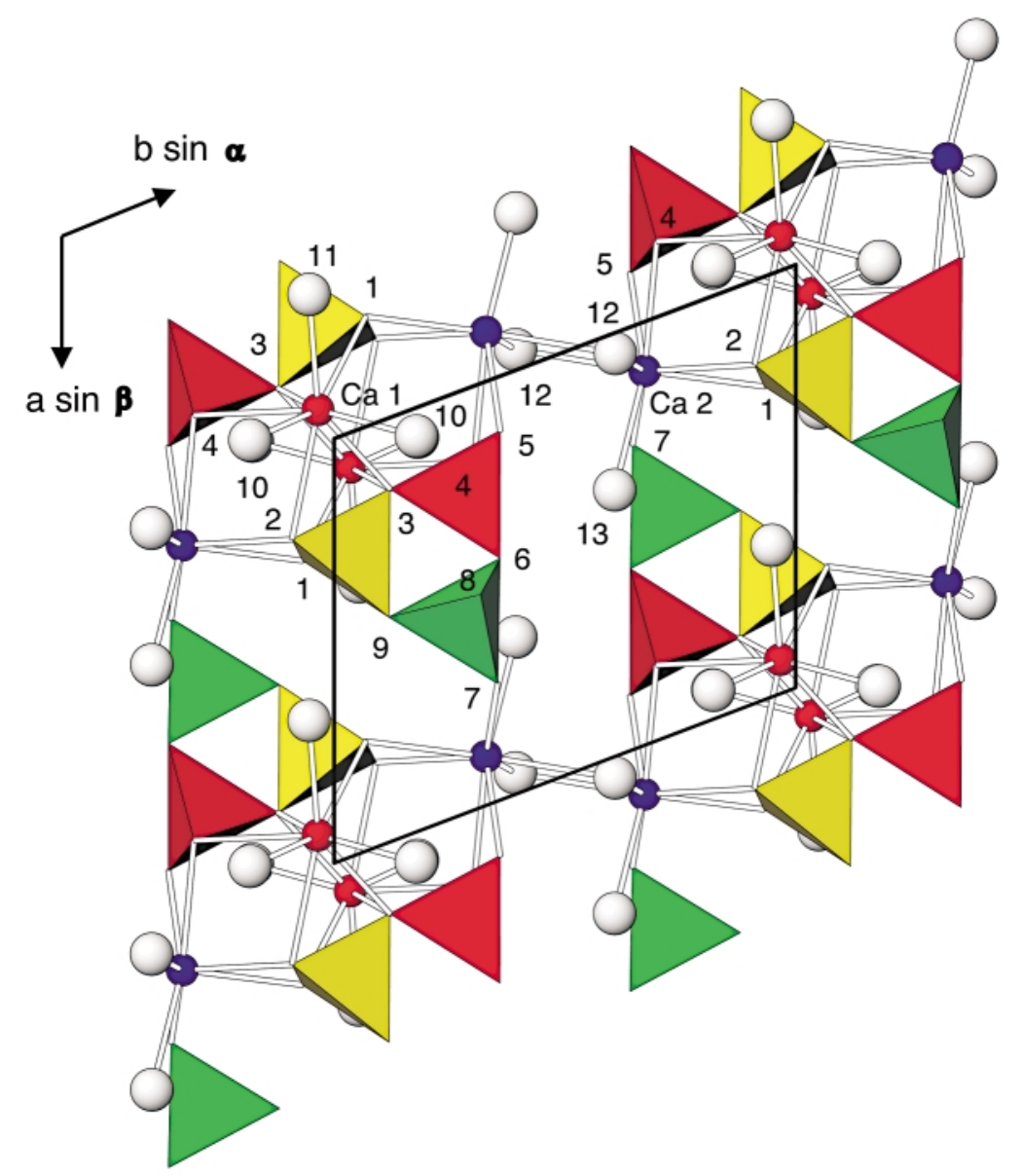

FIG. 1. Projection of the structure of olshanskyite along [001]. H atoms are not drawn.

hedra, which share the edge formed by centrosymmetrical O12-O12 atoms, connect the chains of $\mathrm{Ca} 1$ polyhedra along the [010] direction. Each $\mathrm{Ca} 2$ polyhedron shares respectively one corner $(\mathrm{O} 1)$ and one edge (O2-O4) with two adjacent $\mathrm{Ca} 1$ polyhedra in each chain. The network so obtained is founded upon the repeat of eight-membered rings of calcium polyhedra.

\section{The hydrogen bonds}

Thirteen hydrogen atoms are present in the asymmetric unit: six of them $(\mathrm{H} 1, \mathrm{H} 2, \mathrm{H} 4, \mathrm{H} 5, \mathrm{H} 7$ and $\mathrm{H} 8)$ form hydroxyl groups with the unshared atoms of oxygen $(\mathrm{O} 1, \mathrm{O} 2, \mathrm{O} 4, \mathrm{O} 5, \mathrm{O} 7$, and $\mathrm{O} 8)$ in the borate ring; another hydrogen atom (H10) is part of a hydroxyl group with $\mathrm{O} 10$. Finally, the remaining six hydrogen atoms (H11a, H11b, H12a, H12b, H13a and H13b) form $\mathrm{H}_{2} \mathrm{O}$ molecules with the $\mathrm{O} 11, \mathrm{O} 12$ and $\mathrm{O} 13$ oxygen atoms.
The sites of all hydrogen atoms lie on, or fairly near, the line segment traced between the sites of two oxygen atoms, which act as donor and acceptor, respectively, of one of the thirteen hydrogen atoms in the corresponding hydrogen-bonds. The sites of all hydrogen atoms are 0.84 to $0.93 \AA$ from the donor oxygen atoms belonging to the hydroxyl or $\mathrm{H}_{2} \mathrm{O}$ groups. For eleven of the thirteen hydrogen bonds, the H...O distances with the acceptor oxygen atoms range from 1.7 to $2.1 \AA$, and the corresponding $\mathrm{O}$...O distances between donor and acceptor oxygen atoms range from 2.62 to $2.99 \AA$. In the other two hydrogen bonds, H...O and O...O lengths are somewhat longer: H10...O8: $2.41 \AA$, O10...O8: $3.26 \AA$ and H12b...O7: $2.43 \AA$, O12...O7: $3.25 \AA$.

Only three hydrogen bonds $(\mathrm{O} 1-\mathrm{H} 1 \ldots \mathrm{O} 9$, O7$\mathrm{H} 7 \ldots \mathrm{O} 5$ and $\mathrm{O} 8-\mathrm{H} 8 . . . \mathrm{O} 6)$ join oxygen atoms of the borate rings (Fig. 2). Only one hydrogen bond (O12$\mathrm{H} 12 \mathrm{a} . . . \mathrm{O} 10)$ connects two oxygen atoms external to the 


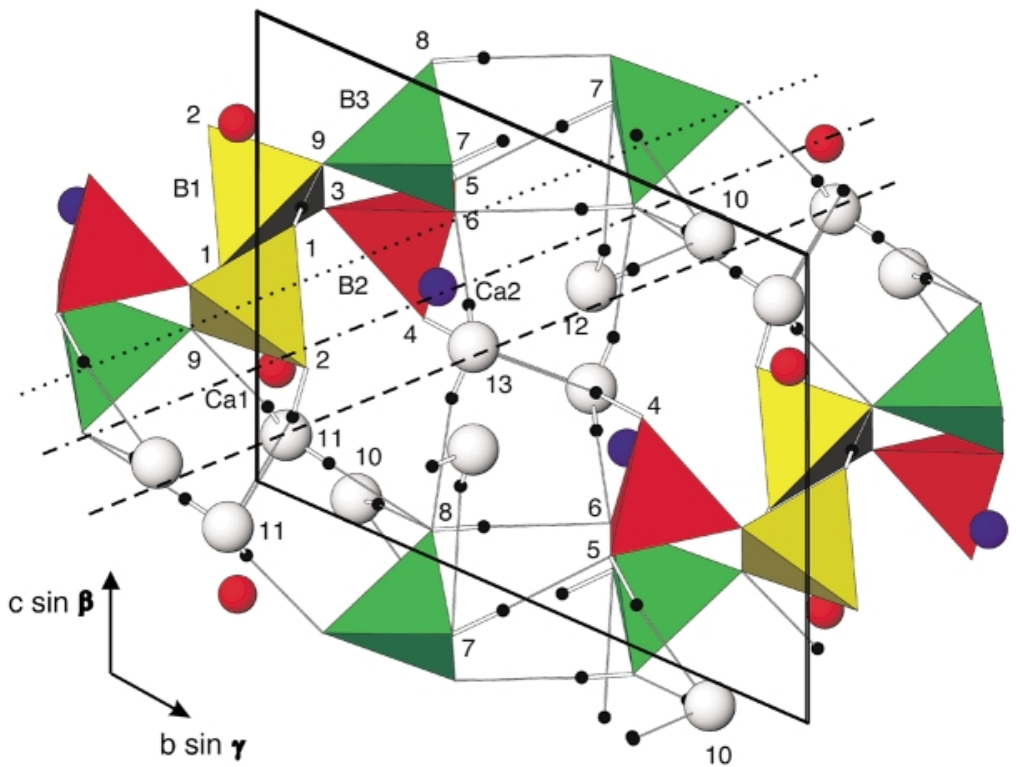

FIG. 2. Projection of the structure of olshanskyite along [100]. Only bonds in which H atoms are involved are traced. The lines indicate the traces of three planes parallel to $(0 \overline{1} 1)$ on which are located, respectively, the centers of borate tetrahedra (dotted line), $\mathrm{Ca}$ atoms (dash-dotted line), and the oxygen atoms of $\mathrm{H}_{2} \mathrm{O}$ molecules and the unique hydroxyl group (dashed line).

borate cluster. However, in the majority of cases, the hydrogen bonds (nine of thirteen) link one oxygen atom (from $\mathrm{O} 1$ to $\mathrm{O} 9$ ) of the tetrahedral borate cluster and one oxygen atom external to the cluster (from $\mathrm{O} 10$ to O13). Table 4 clearly shows that the hydrogen bonds are complementary to the $\mathrm{Ca}-\mathrm{O}$ bonds: in fact, only the oxygen atoms (from O5 to O9) that are bonded to less than two $\mathrm{Ca}$ atoms in the borate cluster (Fig. 3) are acceptor anions in the hydrogen bonds.

Bond valences relative to the hydrogen bonds (Table 4) were calculated using the diagram (H...O bond valences versus $\mathrm{H}-\mathrm{O}$ bond lengths) reported as Figure 1 in Brown \& Altermatt (1985, p. 247). The O-H bond valences relative to the donor oxygen atoms were obtained by subtracting the $\mathrm{H} . . . \mathrm{O}$ bond valences from 1.0. This approach implies that different $\mathrm{O}-\mathrm{H}$ bond valences may correspond to equal $\mathrm{O}-\mathrm{H}$ bond lengths. Furthermore, as the $\mathrm{H}$ sites deriving from the refinement of the crystal structure appear to be closer to the donor anion than they actually are, and following the suggestion by Brown \& Altermatt (1985) to consider more realistic the $\mathrm{H}$ site at $0.95 \AA$ from the donor, an amount of $0.1 \AA$ was subtracted from all $\mathrm{H}$...O lengths before calculating the corresponding bond- valences.

\section{Comparison of the Structures of Olshanskyite AND Nifontovite}

Among the borate minerals, only nifontovite $\mathrm{Ca}_{3}\left[\mathrm{~B}_{3} \mathrm{O}_{3}(\mathrm{OH})_{6}\right]_{2} \cdot 2 \mathrm{H}_{2} \mathrm{O}$ has three-membered rings of borate tetrahedra similar to those found in olshanskyite (Simonov et al. 1978, Hawthorne et al. 1996). However, apart from the obvious analogies between the two structures due to: 1) the identical nature of the four atomic components $(\mathrm{Ca}, \mathrm{B}, \mathrm{O}, \mathrm{H}), 2)$ the similar borate cluster, and 3) the eightfold coordination of the $\mathrm{Ca}$ ions, which also are arranged in layers, no other similarities are apparent. The reduced number of calcium atoms and of oxygen atoms extraneous to the borate ring (i.e., three calcium atoms and two oxygen atoms per two borate rings instead of four calcium atoms and eight oxygen atoms as in olshanskyite) makes the crystal structure of nifontovite more compact. In fact, the density of nifontovite is $2.36 \mathrm{~g} / \mathrm{cm}^{3}$, whereas that of olshanskyite is $2.19 \mathrm{~g} / \mathrm{cm}^{3}$.

In nifontovite, the borate ring is more regular than that in olshanskyite; all three crystallographically independent tetrahedra are arranged as is the B1 tetrahedron in olshanskyite, and each of them shares two edges with 


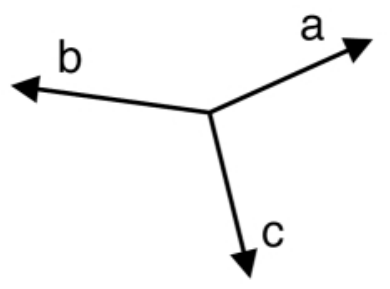

Ca 2

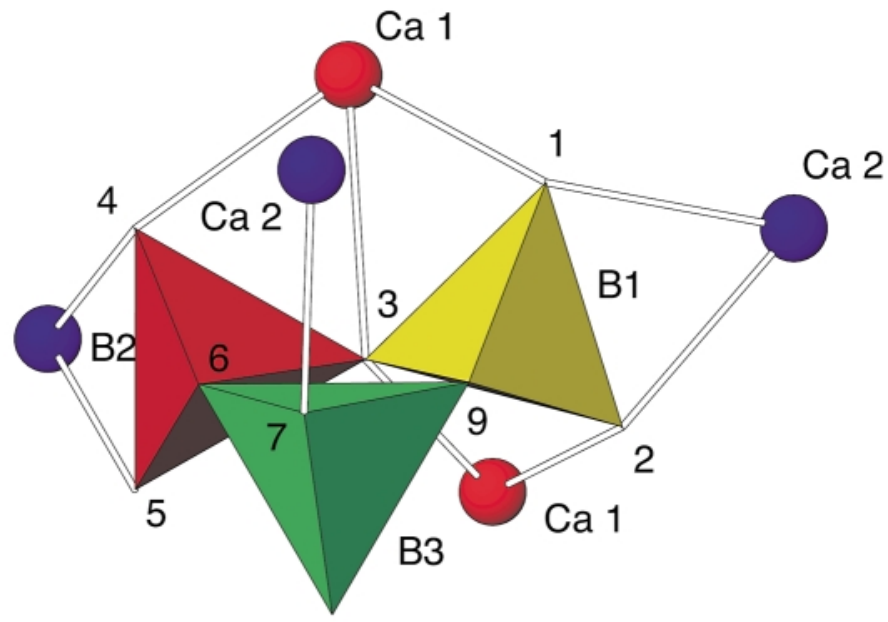

8

FIG. 3. The anionic group $\left[\mathrm{B}_{3} \mathrm{O}_{3}(\mathrm{OH})_{6}\right]^{3-}$ and its bonds with calcium. Note that the three tetrahedra are bonded differently to $\mathrm{Ca}$ atoms.

the calcium polyhedra, whereas in olshanskyite the connections between the Ca polyhedra and boron tetrahedra are different. Finally, whereas in olshanskyite the calcium polyhedra are linked with the formation of a two-dimensional network, the calcium polyhedra in nifontovite form zigzag chains, also arranged in a layer, but without any direct contacts.

\section{DISCUSSION}

The formula unit $\mathrm{Ca}_{2}\left[\mathrm{~B}_{3} \mathrm{O}_{3}(\mathrm{OH})_{6}\right](\mathrm{OH}) \cdot 3 \mathrm{H}_{2} \mathrm{O}$ and the unit cell of olshanskyite derived from the structural results are different from those reported in the papers by Bogomolov et al. (1969) and Kusachi \& Henmi (1994). However, the experimental data obtained by these authors can be equally interpreted according to the new formula unit and the new unit cell, as shown in Table 5. Actually, their unit cell derived from the X-ray powder data is easily transformed into the new one by dividing by 2 the $b$ parameter and by reducing the cell so obtained (Table 5, columns A and B). This operation is clearly not consistent with the presence of the reflections with $k$ odd in the X-ray powder diagram (Table 4 of the paper by Kusachi \& Henmi 1994). However, re- indexing the powder pattern of Kusachi \& Henmi (1994) from a theoretical powder pattern calculated from our structure produces an indexing consistent with our space group (i.e., $k \neq 2 n+1$ ).

The chemical composition inferred from the crystal structure (Table 5, column C) fits fairly well with the observed chemical composition (column A), even if the agreement of the latter data with the formula given by Kusachi \& Henmi (1994) is slightly better (column B). Finally, the concordance between the observed and calculated density $\left(2.19\right.$ versus $\left.2.20 \mathrm{~g} / \mathrm{cm}^{3}\right)$ favors the chemical composition given in the present paper.

On the basis of the results of our research, olshanskyite is a neso-triborate (Strunz 1997), and its crystal structure is based on finite borate clusters ( $\mathrm{FBB}=3 \square$, Hawthorne et al. 1996).

\section{ACKNOWLEDGEMENTS}

We thank the referees P.C. Burns, S. Filatov, F.C. Hawthorne and S.V. Krivovichev, and the editor, R.F. Martin, for their helpful comments. Many thanks also to Dr. V. Mattioli, keen collector of minerals, who provided the specimen of olshanskyite from Japan. 


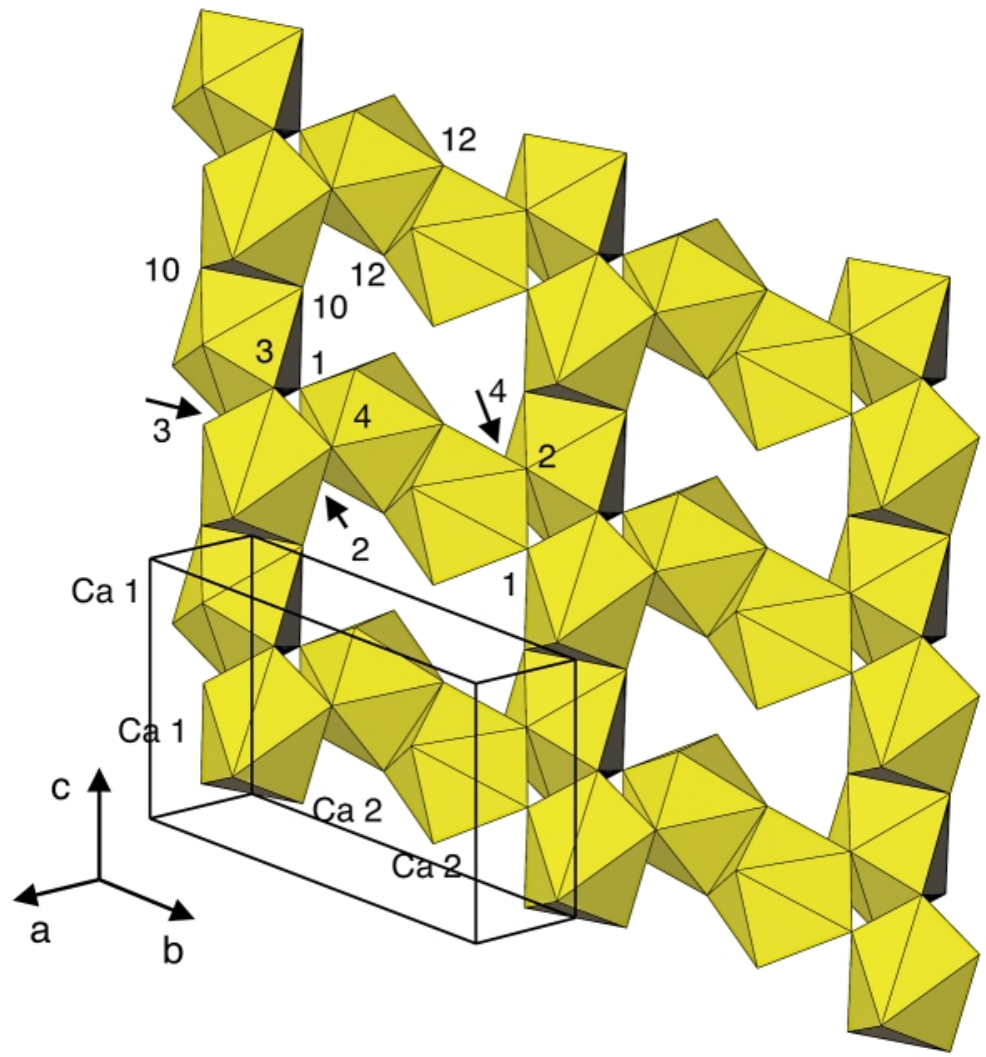

FIG. 4. The network of Ca polyhedra in the plane (100). The connections among calcium polyhedra define a network of eight-membered rings.

TABLE 5. FORMULA UNIT, DENSITY AND UNIT CELL OF OLSHANSKYITE: COMPARISON BETWEEN THE OLD AND NEW RESULTS

(A)

\begin{tabular}{l}
\hline \\
$\mathrm{CaO}$ wt\% \\
$\mathrm{B}_{2} \mathrm{O}_{3}$ \\
$\mathrm{H}_{2} \mathrm{O}(+)$ \\
$\mathrm{H}_{2} \mathrm{O}(-)$ \\
total \\
Ca apfu \\
B \\
$\mathrm{H}$ \\
O
\end{tabular}

1.21
(B)

34.50
29.64
34.54

99.89

100.00

$2.91 \approx 3$

$4.02 \approx 4$

$18.02 \approx 18$

18.00

34.50
(C)

33.61
31.30
35.09
100.00
$2.10 \approx 2$
$2.91 \approx 3$
$13.09 \approx 13$
13.00

13.00
(A)

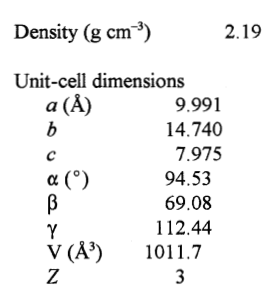

(B)

(C)

2.20

$35.84-33.61$

$29.66 \quad 31.30$

2.31

(A) Chemical composition and measured density; unit cell derived from X-ray powder data (Kusachi \& Henmi 1994).

(B) Formula unit from the data of column (A) and calculated density (Kusachi \& Henmi 1994); the unit cell is the same of column (A), but transformed according to the matrix $00 \overline{1} / 1 \frac{1 / 2}{2} 0 \neq 0 \overline{1 / 2} 0$.

(C) Formula unit from the data of column (A) and calculated density; unit cell obtained from single-crystal X-ray diffraction (present work). 


\section{REFERENCES}

Bogomolov, M. A., Nikitina, I.B. \& Pertsev, N.N. (1969): Olshanskyite, a new calcium borate. Dokl. Acad. Sci. USSR, Earth Sci. Sect. 184, 127-131.

BRESE, N.E. \& O'KeEFFe, M. (1991): Bond-valence parameters for solids. Acta Crystallogr. B47,192-197.

BRown, I.D. \& AltermatT, D. (1985): Bond-valence parameters obtained from a systematic analysis of the inorganic crystal structure database. Acta Crystallogr. B41, 244-247.

Busing, W.R., Martin, K.O. \& LeVy, H.A. (1962): ORFLS. Oak Ridge Natl. Lab., Oak Ridge, Tennessee, Rep. ORNLTM-305.

Hawthorne, F.C., Burns, P.C. \& Grice, J.D. (1996): The crystal chemistry of boron. In Boron: Mineralogy, Petrology and Geochemistry (E.S. Grew \& L.M. Anovitz, eds.). Rev. Mineral. 33, 41-115.
KuSACHI, I. \& HENMI, C. (1994): Nifontovite and olshanskyite from Fuka, Okayama Prefecture, Japan. Mineral. Mag. 58, 279-284.

North, A.C.T., Phillips, D.C. \& Mathews, F.S. (1968): A semi-empirical method of absorption correction. Acta Crystallogr. A24, 351-359.

Simonov, M.A., Egorov-Tismenko, Yu.K., KaZAnskaya, E.V., BelokoneVA, E.L. \& Belov, N.V. (1978): Hydrogen bonds in the crystal structure of nifontovite, $\mathrm{Ca}_{2}\left[\mathrm{~B}_{5} \mathrm{O}_{3}\right.$ $\left.(\mathrm{OH})_{6}\right]_{2} \cdot 2 \mathrm{H}_{2} \mathrm{O}$. Sov. Phys. Dokl. 23,159-161.

STRUNZ, H. (1997): Classification of borate minerals. Eur. J. Mineral. 9, 225-232.

UNGARETTI, L. (1980): Recent developments in X-ray single crystal diffractometry applied to the crystal-chemical study of amphiboles. God. Jugoslav. Kristalogr. 15, 29-65.

Received July 23, 2000, revised manuscript accepted December 24, 2000. 